\title{
How to Manage Yourself: "Feminism" and Recovery in the New Managerial Discourse
}

\author{
Jennifer Henderson
}

\begin{abstract}
En ce moment historique où la culture nord-américaine est obsédée par les mouvements de croissance personnelle/connaissance de soi, et où les corporations sont consummées par la mise à pied et la restructuration, Henderson analyse les points de rencontre entre le féminisme de rétablissement et les nouveaux discours directoriaux. Elle argumente que les programmes de croissance personnelle/connaissance de soi à l'intérieur du féminisme de rétablissement (par example, The Revolution From Within (La révolution intérieur) de Gloria Steinem) offrent un concept de soi-devenir un être humain à travers la guérison-qui est facilement coopté et utilisé dans les discours directoriaux: un discours basé sur la façon de donner le pouvoir aux gens de se gérer eux/elles-même et de donner plus de leur personne à la compagnie. L'analyse Foucaultienne de Henderson démontre clairement que le chemin vers la guérison de soi dans le mouvement de survie et l'impératif de prendre contrôle et de prendre conscience de son enfant intérieur dépend du modèle d'auto-gouvernement de soi trop facilement adaptable dans les agendas d'auto-dépendance des corporations et des gouvernements. La réalisation de soi et le gain de pouvoir sur soi arrivent à un moment où les corporations et les gouvernements retirent leur soutien au système d'aide sociale. Les sujets sont appellés à se réaliser dans leur travail et ce discours les empêche de se rendre compte que les conditions de travail dans la nouvelle économie globale demandent qu'elles/ils travaillent plus pour un salaire moindre.
\end{abstract}

A scan of current management literature would reveal that such titles as "The Feminization of Management," The Female Advantage, The Healing Manager, "The Search for Spirit in the Workplace," "From Domination to Partnership," "From Paternalism to Stewardship" are dominating the shelves. Human resource departments are addressing injunctions to employees in the language of "self-esteem," "inner potential," "empowerment" - even "healing." This all gives a feminist of the late twentieth 
century an eerie feeling of déja vu, for these are the catch-words of a feminism which problematizes feelings of inadequacy, powerlessness and dependency, and which has become popularized as recovery feminism.

I wish to outline some discursive complicities in the workplace of the new economy, where programmes for getting free function as the means by which subjects are expected to govern themselves in relation to the exigencies of employment without security or benefits. The working self is currently the target of governmental technologies which operate through self-scrutiny and -regulation, the capacity to problematize oneself as "dysfunctional," "codependent," a sufferer of low "selfesteem," even-and especially-a victim of "patriarchal power." Understanding the work that feminist discourses are doing in this terrain may be important to developing an anti-managerial politics in a time of increasing corporate control.

This essay is also, necessarily, part of a larger project to argue for feminist wariness in relation to tropes of recovery. In The Culture of Recovery: Making Sense of the Self-Help Movement in Women's Lives, Elayne Rapping traces the path from the 12-Steps model of Alcoholics Anonymous to the wider recovery movement which, she argues, has replaced second-wave feminism while borrowing some of its main themes. For Rapping, there is still a coherent feminism which is simply off somewhere wintering as its ideas are being deployed by another movement which has risen to prominence during this temporary lull in the progress of the real (feminist) "social and cultural revolution in the making, halfway home, getting tired and doubtful, confused and scared" (63). She takes comfort in the recovery movement's dependence on feminist ideas, finding heartening evidence of feminism's progressive influence in the fact that today, "even reactionaries must address matters of gender and private life" (185). I think it is unwise to rejoice at this instrumentalization of feminist ideas, however. By insisting on the term recovery feminism, I mean to imply that recovery is not feminism's other, but that it in fact builds on aspects of cultural and liberal feminism. This calls for something more difficult than a faith in political progress: instead of congratulating ourselves on the popularization of some feminist ideas, in other words, we should be asking what ends that popularization is serving.

Recovery feminism finds its way into the workplace through the human resource function, and more specifically through training programmes which address the workers of the new economy as victims of an "old paradigm" of employment, "seduced and conditioned into 
letting themselves be captured, often putting their self-esteem and sense of relevance into the company vault" (Noer 210). This may appear to simply recirculate the responsibility to help oneself out of a state of dependency which is already widely promoted by neo-liberal Western governments in the process of withdrawing from the role of social security providers. However, when it appears in managerial discourse, the injunction to help oneself is specifically framed in an infantilizing language of recovery which implicitly has as its model the little girl deprived of a sense of self. A liberal feminist discourse on female leadership also comes into play here, for the management literature puts this injunction to recover in the mouth of the new female manager, who is supposedly poised to effect a "revolution" in the "dysfunctional" "patriarchal" organization with her new style of nurturing management.

The representation of the current shift in management approaches in terms of a switch from masculine to feminine models of power is supposed to provide a pre-approved allegory of progressive transformation. Conjugated with a "womanpower" "deeper than the patriarchy" and entirely distinct from "power-over" (Gearhart 197, 195), managerial authority picks up the aura of being "never harmful and always helpful" (Schaef 174). By positing the overwhelming victory of liberal feminism (we are supposed to believe that there are now armies of women at the top levels of management) the new managerial discourse also grounds the norms of conduct it will promote in the "evident" meritocratic justice of the promotion of individual women. If the feminization of management is the result of the removal of barriers to individual female success- "bounties and duties in favour of men" as John Stuart Mill called them-the change that it will effect at the level of management approaches will be the application of precisely the same principle to workers. Thus, the revolution in the patriarchal workplace will mean lifting the barriers to self-realization, by "creating opportunities for employees to take care of themselves" (Ehrlich 491). The workplace of the new economy is not restructured or downsized, but rather "liberalized"; it is not that new demands are being placed on workers or that conditions of employment are less and less secure, but rather that the artificial barriers to the free market of competition for individual success are being removed. As a worker, you are simply being invited to "be you" at work-a "thinking, contributing adult and not just... another interchangeable part of the organization" (Townsend and Gebhart 8-9). This "you" is described in the discourse both in terms of the "businessed" 
self and the volunteer, the employee who operates as if $s$ / he were a oneperson business and the volunteer who is selflessly devoted to the mission of the firm. The contradiction is only superficial, as both metaphors emphasize the new kind of claim on workers: it is no longer satisfactory to simply sell one's labour, one is expected to make work the privileged arena for personal growth.

The Female Advantage: Women's Ways of Leadership is one of the texts on "feminine principles" of management which —in a perfect liberal combination of justice and expediency - anchors itself firmly in the exigencies of corporate restructuring. "What business needs now is exactly what women are able to provide, and at the very time when women are surging into the workforce": an ability to "bridge the gap between the demands of efficiency and the need to nurture the human spirit" (39, 234). This gap is to be bridged with the natural talent of the female manager, who is pictured on the cover as a goddess with her distaff raised triumphantly. In this book, she weaves intimate "webs of inclusion" which help "get union stewards and plant managers past their antagonistic, us-versus-them presumptions" (144). Zapp! The Lightning of Empowerment: How to Improve Quality, Productivity, and Employee Satisfaction, is another management text that naturalizes the new techniques as a "female advantage," but the emphasis here is on how this advantage can be appropriated by the male manager. In Zapp's "fable," Lucy Storm is the model manager, the bearer of a magic wand for "zapping" her employees into high self-esteem and high productivity. Joe Mode is an old-style male manager and the narrative questor who must discover Lucy's secret. By the end of the story, he has discovered Lucy's technique through trial and error and transformed his own department: "When he opened his eyes, Joe saw Dept $\mathrm{N}$ in a light in which he had never seen it before. The fog had lifted. As he walked around, it was as if the sun had come out, except that the sun was inside the people.... [T] he stone walls were tumbling and crumbling. The glass walls had been vaporized. ... Everybody in Dept $\mathrm{N}$ was growing into exactly what they were- human beings" (129).

The statement that is repeated again and again in the new managerial discourse is that human resources are key to the survival of organizations in the global economy. To be "human" at work means to engage in the paradoxical combination of transformation and stasis suggested by the idea of "growing into" what one has always been. In becoming "human," Joe's employees are following the same path as the model 
recoverer who rediscovers a forgotten inner core, or the addressee of the epigraph to Gloria Steinem's The Revolution From Within: A Book of SelfEsteem, "You have come here to find what you already have." They become "human" precisely to the extent that they bring to work the capacity for relating to the self as material to be cultivated, monitored, evaluated, "esteemed" (Cruikshank 334). The capacity to subject one's self to scrutiny in this way is not essentially and universally "human," but the result of a wide dissemination of exercises in ethical self-regulation or "techniques of conscience" that were originally specialized religious practices but were gradually incorporated by modern bureaucratic states as "economical" means of managing populations. Foucault calls this rationalization of the exercise of power "governmentality": it is a machinery of social administration that produces cooperative citizens by inciting them to particular forms of self-interest-autonomy, wellbeing, security, "a little extra life," by means of which the state can supply itself with "a little extra strength" (1980-81 248). The same art of government is ideally suited to a cost-cutting mode of production because it permits the expensive middle layer of management to be replaced with employee self-governance, or what the owner of one manufacturing plant calls a programme of "Empowerment or Else."

Like the Christian shepherd who exercises "pastoral power" by recommending to each and every member of his "flock" a vigilant practice of self-examination, the nurturing manager gains access to the relation that workers entertain with themselves by delegating to each and every one the responsibility for self-monitoring according to a particular "game of truth." A recovery programme can be thought of as a two-step game of truth: first one admits to powerlessness and then one discovers a source of power in a lost self situated at some temporal distance but nevertheless in the close proximity of one's inside. This lost self is buried deeper the more "patriarchal" "power-over" one has had to endure; but the further it has to travel to the surface, the more potential one has to go forth and realize in the world. It is the project of realizing this "resistant, daydreaming, rebellious, creative, unique child" (Steinem 51) that is susceptible to multiple application in the field of relations of work. When recovery discourse makes its way into a management vocabulary, pickyour-self-up-by-your-bootstraps-ism is crossed with metaphors of depth and truth, so that we have something like the excavated inner child as the model worker of the new economy, recuperating losses and realizing stored potential by growing up at and through work. When 
this is legitimated by a discourse on female leadership with claims to being antithetical to power and hierarchy and to being capable of replacing "militaristic male power" with a "Female System" of empowerment and nurturing in which "issues of control and controlling have no place" (Schaef 174), it is time to ask what feminism is being made to authorize.

It is not so much a discourse on female leadership as the moral weight of a feminist leader that authorizes the government of welfare recipients through the "truth" of their "codependency" when Gloria Steinem lends uncritical support in The Revolution From Within to the California Task Force to Promote Self-Esteem and Personal and Social Responsibility, a campaign to reduce demands on the state by pathologizing non-entrepreneurial forms of relation to self and prescribing recovery programmes as a "social vaccine." Like most self-help books, The Revolution From Within is a series of biographical parables, but what makes it a text in recovery feminism specifically is its use of the figure of the little girl— "discouraged from strength and exploring, ... punished for wilfulness and praised for assuming a docility and smiling sweetness she doesn't feel" - as the model for the shamed subject in need of recovery (67). Dispensing with the connection between self-esteem and the capacity to sustain a political struggle that was central to second wave feminism's interest in the problem of "internal oppression," Steinem universalizes the problem of "inner shame": we are all shamed little girls, "anyone, anywhere, female or male, who is devalued so deeply that inferiority seems to be inherent in the reality of his or her own body," anyone from an inner-city dwelling black welfare recipient, to a middleclass American lesbian, to Ghandi, to post-Soviet Russia.

The privileging of a doubly remote, internal and past experience of victimization has the advantage of minimizing the kind of racial, economic, and geopolitical differences and inequalities between women which have, since the 1980s, necessitated a reckoning with problems of structured ignorance and complicity in feminism. Steinem's desire to recentre the authority of "supposedly privileged and powerful women" is particularly naked when she figures her personal discovery of the "inner child" in terms of a garden "that had grown beneath the shadow of barriers for so long that it kept growing in the same pattern, even after some of the barriers were gone" (3; my emphasis). When one is stronger for having been broken, braver for having had to conquer these invisible barriers-as the logic of recovery goes-it becomes possible to attribute 
the prestige of someone like Steinem to hardship, or, as she puts it in her confessional preface, to an experience of healing from "co-dependen[ce] with the world" (8). If we read the move to privilege a universal identity of wounded inner cores in the context of the irruption of debates within late 20th-century feminism, the implication is that those white middleclass feminists enjoying positions of relative institutional privilege deserve to be at the top because they have intimate experience of the psychological problems that persist "even after some of the barriers [are] gone."

A feminism so redefined as a recovery movement would, however, need to legitimate itself by demonstrating its ability to also address the needs of those women unable to situate themselves in the "aftermath" of external barriers. When Steinem chooses to tell the parable of "The Women of Ahmedabad," "the poorest of India's workers" turning their lives around with a single, shame-defying act, it is necessary for her to focus on the shamed female body rather than the conditions of "Third World" female labour, if the parable is to function as an authentication of the universal claims of western recovery feminism. Risking the crossing of a river in order to get to a temple which forbids the entry of menstruating women, the women discover that their bodies are not unclean after all when their boat crosses the river safely: thanks to a Hindu taboo on the menstruating body, they have had an opportunity to be brave. This is the lesson in self-realization through the overcoming of obstacles that the American feminist would teach the South Asian peasant woman, just as she would have international "development experts" turn their efforts towards "'soft' factors such as 'national inferiority complex" and "'belief in reward for work'," in a new kind of civilizing mission (13).

Although its model recoverer is the damaged little girl, Steinem's recovery feminism borrows the weight of a triumphantly masculinist and imperialist nineteenth-century self-help discourse. I want to take a moment to describe an instance of this discourse in Samuel Smiles' 1859 text, Self-Help, in order to argue for the importance of looking further back than Alcoholics Anomymous for the sources of recovery feminism, even to as unlikely a candidate for feminist inspiration as Smiles, because an awareness of the links between nineteenth-century self-help and imperialism may push us to consider the current relation between recovery feminism and the social relations of production in a global economy. In Self-Help, Smiles relates the careers of a number of accomplished 
English men in the form of biographical parables which illustrate the development of a masculine force of character through an early struggle against adverse circumstances (the injunction to help oneself has not yet passed through feminism, which will give it a psychological turn and make it a response to positive oppression, not just the absence of financial means). The material hardships suffered by Smiles' self-made men-imperial officers, industrialists, inventors, missionaries-force them to take up a manual trade and thus to learn a particularly gendered "will to labour energetically and perserveringly" which is measurable, according to Smiles, in the force of their hammer strikes (148). This virility, which is comparable to the stored potential of the recoverer in Steinem, has a value not just for the individual but also for the nation, because the aggregate effect of the personal improvement of men is national progress, and conversely, the sum of "individual idleness, selfishness and vice" is "national decay" (20). The logic extends to a moralistic imperialism which permits Smiles to argue that it is part of the "just balance of nature [that] individuals, nations, and races will obtain just so much as they deserve, and no more. And as effect finds its cause, so surely does quality of character amongst a people produce its befitting results": India, from this perspective, is nothing but a "great field for the display of British energy" $(231,152)$.

This may appear to be a far cry from the comparatively benign-seeming discourse of recovery feminism, but when courageous recovery is tied to the priorities of the corporation in a global economy, recovery feminism's debt to this kind of meritocratic and imperialist self-help becomes clearer. In appropriating this strand of feminism, managerial discourse has borrowed constructs deployed in the struggle of privileged women to remain the defining centre of the movement, constructs which permit a replication of the universalizing move in the context of relations of production. Let me elaborate on this point by returning to the best-selling management "fable," Zapp! , where the self-esteeming of a problem employee demonstrates how the civilizing mission of recovery would transform a diverse workforce into teams of little white boys ripe for competition in the global economy.

Zapp! presumes a workplace transformed by affirmative action (this, in fact, is one of the crises that it aims to manage). When Joe Mode learns that the secret of female leadership which is causing increased productivity in the female-headed departments all around him is "zapping" enhancing the self-esteem of one's underlings by forcing them to assume 
the responsibility of self-monitoring - he changes his title to "group leader" and introduces a new disciplinary regime in his department which consists of chalkboards charting the progress of each employee. Instead of being a new way of governing employees through the visible quantification of their effort, this initiative is an exercise in power sharing. But a management problem arises in relation to an ethnicallymarked older female employee, "Mrs. Estello," who is, perhaps not surprisingly, an incompetent reader of the progress chart which represents her as a team member whose desires are seamlessly matched with the "quality and efficiency" goals of the company. "Unfortunately, the new goals required more information to be processed by Mrs. Estello, who was still making mistake after mistake with hardly any break" (113).

Joe discovers the solution to this snag in the smooth unfolding of the company's desires during his quality time at home as a parent, whilst teaching his son how to bat a baseball: "little Moe was not a natural baseball player; he had succeeded because his dad had taken the time to coach him and because he had practiced. And as Joe watched proudly while little Moe ran the bases, he suddenly realized that this is what he had to do with Mrs. Estello" (116). The metaphorics of the sports team are not accidental, for the manager as coach and the employee as team player are some of the preferred figures in the new managerial discourse for relations in the downsized corporation-where being a good sport means leaving the union, trusting the caring manager, and "giving it your all" at work. What is so interesting about Zapp! is the way its narrative stages a masculine articulation of the discourses of nurturing leadership and employee empowerment through the anxious white male manager's esteem-building discovery of a masculine metaphorics for Lucy's secret management technique: as Mrs. Estello is coached out of her dependency syndrome into the more "mature" practice of self-management, "employee empowerment" turns out to mean producing little white boys as commodities in a world that no longer permits the company to hire them. The secret of female leadership will consist of coaching employees into boyhood, producing the homosocial cooperation of a team fit for the vicious global tournament of the new economy, by eliminating the difference-the resistance - of someone like Mrs. Estello.

It was not a steady climb for Mrs. Estello. From time to time, she would get angry at Joe for having her do things she didn't want to do. Or she would become defensive about her performance. Or she 
would get the idea that Joe was manipulating her, and her trust in him would weaken. And then she would slip back into her old ways and attitudes.

When that happened, Joe Mode relied upon the key principles he had learned to get her back on her upward path again. He did it by maintaining her self-esteem, listening and responding with empathy, asking for help in solving problems, and offering help without taking responsibility away from her.

Sure enough, Mrs. Estello would begin to improve again. (Zapp! 121) This is not a cruel twist that Joe Mode puts on a benign form of female leadership, for I would suggest that recovery feminism already contains these infantilizing and normalizing moves, promising a paradoxical form of "liberation" which requires self-government through a set of ready-made truths. By filling out recovery with a process of boying that is a reminder of the virile masculinity of Smiles' self-helping subject, poised to display his courage across the empire, and by demonstrating the stakes of a universalizing discourse on female leadership for Mrs. Estello (who has less hope of achieving a managerial position than Joe's son), Zapp! demonstrates some of the dangers of the personal transformations we may imagine ourselves to be effecting all on our own. If feminism is going to have a hand-even inadvertently-in the development of managerial forms of power, we need to develop ways of critically engaging with those forms of kindly power which anchor themselves in feminine authority and govern in the name of a permanent freedom from adversity.

\section{Works Cited}

Thanks to Katherine Binhammer, Keith Denny, Daniel O'Quinn and Peter Sinnema for their comments on earlier drafts.

Block, Peter. "From Paternalism to Stewardship." Training (July 1993) 45-50.

Byham, William. Zapp! The Lightning of Employee Empowerment. New York: Fawcett-Columbine, 1992.

Cruikshank, Barbara. "Revolutions Within: self-government and selfesteem." Economy and Society 22.3 (August 1993) 327-44.

Eisler, Riane. "From Domination to Partnership." Training and Development 49.2 (February 1995) 32-39. 
Ehrlich, Clifford J. "Creating an Employer-Employee Relationship for the Future." Human Resource Management. Special Issue on

"Psychological Contracts." 33.3 (Fall 1994) 491-502.

Foucault, Michel. "Governmentality." The Foucault Effect: Studies in Governmentality. Eds. Graham Burchell et al. London:

Harvester/Wheatsheaf, 1991: 87-104. . "Omnes et Singulatim: Towards a Criticism of 'Political

Reason'." The Tanner Lectures on Human Value. Ed. S. M. McMurrin. Cambridge: Cambridge UP, 1980-81.

Frey, Robert. "Empowerment or Else." Harvard Business Review.

(September-October 1993) 80-92.

Gearhart, Sally. "Womanpower: Energy Re-Sourcement." The Politics of Women's Spirituality: Essays on the Rise of Spiritual Power Within the Feminist Movement. Ed. Charlene Spretnak. Garden City, NY:

Anchor Press/Doubleday, 1982: 194-206.

Helgeson, Sally. The Female Advantage: Women's Ways of Leadership.

New York: Doubleday Currency, 1990.

Lee, Chris. "The Feminization of Management." Training (November 1994) 25-31.

and Ron Zemke. "The Search for Spirit in the Workplace."

Training (June 1993) 21-28.

Lundin, William and Kathleen Lundin. The Healing Manager: How to

Build Quality Relationships and Productive Cultures at Work. San

Francisco: Berret-Koehler, 1993.

Noer, David M. Healing the Wounds: Overcoming the Trauma of Layoffs

and Revitalizing Downsized Organizations. San Fransisco: Jossey-Bass

Management Series, 1993.

Rapping, Elayne. The Culture of Recovery: Making Sense of the Self-Help

Movement in Women's Lives. Boston: Beacon Press, 1996.

Schaef, Anne Wilson. Women's Reality: An Emerging Female System in a

White Male Society. Third Ed. San Francisco: Harper, 1992.

Smiles, Samuel. Self-Help. [1859] London: Penguin, 1986.

Smith, Albert C. and F. B. Green, "Managing Employees as if They

Were Volunteers." SAM Advanced Management Journal 5.8 (Summer 1993) 42-45.

Steinem, Gloria. The Revolution From Within: a Book of Self-Esteem.

Boston: Little, Brown \& Co., 1992.

Townsend, Patrick L. and Joan E. Gebhardt. "What's in it for me?" Journal for Quality and Participation (March 1993) 8-11. 